\title{
Program for Prevention of a Considerable Number of Premature Births
}

\author{
Erich Saling, Monika Dräger \\ Institute of Perinatal Medicine, Vivantes Klinikum Berlin-Neukölln, Rudower Str. 48, D-12351 Berlin, Germany \\ Tel: +49-(0)30-13014-8335/4, e-mail: info@saling-institut.de,web: www.saling-institut.de
}

\begin{abstract}
Objective: Prevention of prematurity by a prematurity-preventionprogram, including "Self-Care”-measures for the pregnant women.

Introduction: Prevention of early prematurity (<32 gest.w.) and of very low birthweight infants $(<1500 \mathrm{~g})$ is one of the most urgent tasks of perinatal medicine. Particularly ascending genital infection is the most important avoidable cause of early prematurity. For the prevention of these infections the "protective lactobacillus system" plays a crucial role. Bacterial vaginosis and/or ascending genital infection start mostly with a disturbance of this vaginal milieu-which we consider as a "precursor".

Our program is based on an anamnestic assessment of prematurity risk, the early detection of warning signs (including screening for preinfection respectively infection signs by regular measurement of the vaginal $\mathrm{pH}$ ) and, if necessary, the appropriate therapeutic measures. The program includes "Self-Care"-measures by the women themselves (preferably for all pregnant women) and additional special measures for women at risk, for example, the ETCO for women with recurrent premature births.
\end{abstract}

Design and method: The Self-Care-measures for pregnant women are an additional measure to regular prenatal care. In our own study, we had 1120 multiparae and we compared the outcome of the pregnancy with self-care activities with the outcome of the immediate previous pregnancy. Our program was then used in the entire state of Thuringia (Germany). In the second half of the year 2000, the SelfCare Program was employed and the statistically evaluated results for the entire state were compared with those from the first half of 2000 without the program (in each half-year there have been more than 8.000 births). After that, several German health insurance companies used our prenatal-care self-examination program in a pilot project to their pregnant members.

The early total cervix occlusion (ETCO) is a preventive measure particularly for cases with two or more late abortions $(>12+0 \mathrm{gw})$ or early premature births $(<32+0 \mathrm{gw})$ in the patient's history with either infection as cause for these events or when no other cause has been found, but when for instance premature rupture of membranes occurred. The Total Cervix Occlusion creates a complete barrier against ascending infections within the cervical canal (as opposed to the cerclage).

\section{Results}

A. With regards to the Self-Care-measures: In all studies the rate of premature births could be considerably reduced. Most interesting are the results of the prematures at particularly high risk. In our collective, the rate of very low birthweight infants ( $<1500$ g) could be reduced from $7.8 \%$ in the immediate previous pregnancy to $1.3 \%$. In Thuringia, the rate of infants born $<32+0$ gw was reduced from 1.36 to $0.94 \%$ respectively in infants $<1000 \mathrm{~g}$ from 0.61 to $0.38 \%$. After the campaign in Thuringia had been finished, the prematurity rates monitored in 2002 were again as high as before. The first evaluation of a health insurance company in the German state North-Rhine-Westfalia (NRW) shows that the insured patients had a prematurity rate of $7 \%$ compared with the overall prematurity rate in NRW of $9.6 \%$.

B. After an ETCO the rate of surviving infants was about $80 \%$ in our own population (as opposed to $17 \%$ in the pregnancies before the ETCO in the same group). Similar good results have been obtained by other clinicians. With ETCO in multiple pregnancies Schulze (2008) was able to achieve a prematurity rate of only $17 \%$ as against a rate of $29 \%$ in cases without ETCO.

Conclusion: The Self-Care Program for pregnant women proved to be a very efficient method for the prevention of prematurity and should be recommended to every pregnant woman. In cases where this is not possible, at least doctors and midwives should measure the vaginal$\mathrm{pH}$ at each prenatal care examination. The Early Total Cervix Occlusion is an effective preventive measure for women with recurrent late abortions or prematures births and it seems to be also a good measure to prevent premature births in multiple pregnancies. More research in this area is necessary.

Key words: Prematurity prevention, vaginal $\mathrm{pH}$ measurement, vaginal infection, self-care, early total cervix occlusion, protective lactobacillus system.

\section{INTRODUCTION}

Prematurity is still a major problem not only in the field of obstetrics and perinatal medicine but also for the society as a whole not to mention the burdens for the concerned infants and their families. Particularly infants born before 32 weeks of 
gestation (gw) and/or with a birthweight lower than $1500 \mathrm{~g}$ are at considerably higher risk of mortality and morbidity than infants born at term. Serious morbidity caused by prematurity includes respiratory distress syndrome, intraventricular hemorrhage, periventricular leucomalacia and necrotizing enterocolitis. Late sequelae include cerebral palsy, hearing and visual deficits, seizures and cognitive deficits (Berkowitz et al 1993, Hack et al 1994 and 2002, Monset-Couchard et al 1996, Riegel et al 1995, Saigal et al 1989).

The situation is explosive. Despite of all the progress in perinatal medicine, the rate of premature births is increasing, also in developed countries. For example, in Germany, the rate of extremely premature born infants with less than 28 gw has increased from $0.37 \%$ in 2001 to $0.56 \%$ in 2006 (Bundesgeschäftsstelle Qualitätssicherung, several years). This is an increase of 51\%. In the USA, there was a lower increase from $1.81 \%$ in 1981 to $2.0 \%$ in 2004 for the prematures with less than 32 gw (National Vital Statistics Report 2006). The reasons for the increase are probably the increased maternal age as well as the increase of the rate of multiple pregnancies as a result of assisted reproductive technologies.

Another problem, which is particularly relevant for the developing countries, is the increased susceptibility of preterm neonates to infections.

In addition, the financial burden of preterm birth is exceptionally high. For example, the Institute of Medicine of the National Academies of the United States has recently estimated that the cost of preterm birth is \$26 billion per year in that country (Institute of Medicine of the National Academies 2006).

\section{Causes of Prematurity}

A number of reasons are known about late abortions and prematurity. Roberto Romero and his co-workers named it "Preterm Parturition Syndrome" (Romero et al 2006b). The causes are:

- Uterine overdistension

- Ischaemia

- Cervical disease

- Abnormal allograft reaction

- Allergic phenomena

- Endocrine disorder and

- Infections (which are the main emphasis of our program). As far as the avoidable causes are concerned, infections play the main role: ascending genital infection is known to be the main source-particularly of premature births below $32+0$ gw. Back in 1991 (Saling et al 1991, Saling 1991) we were able to find concrete signs of an infection in about three quarters of the infants with a birthweight of less than $2000 \mathrm{~g}$.
The number of cases with premature rupture of membranes, was correspondingly high, namely 55\%.

The association between bacterial vaginosis and prematurity is particularly remarkable. Maternal urinary tract infections ${ }^{1}$ or systemic infections can however, also lead to premature birth.

\section{The Protective Lactobacillus System}

For the prevention of ascending vaginal infection the "protective lactobacillus system” plays a crucial role. We can here only explain the essentials of it, but more details are to be found on: http://www.saling-institut.de/eng/04infoph/01allg.html.

The human vagina possesses a bio-system which under normal conditions provides a balance between physiologic lactobacilli and pathogenic bacterial flora, and so ensures a good protection against the spreading of pathogens, including their ascension to the uterine cavity. In an article of particular interest to us, Gregor Reid (2001) described the role of lactobacilli in urogenital tract infections. The following main functions of lactobacilli are known (Fig. 1):

1. They produce acids, mainly lactic acid.

2. They produce hydrogen peroxide $\left(\mathrm{H}_{2} \mathrm{O}_{2}\right)$, which releases oxygen and has a disinfecting effect. These factors, combined with Bacteriocines inhibit the growth of pathogens which are always present in the vagina.

3. They produce biosurfactants, which cover the surface of the vaginal wall, thereby inhibiting the adhesion of pathogens.

4. They produce coaggregation molecules which block the spread of pathogens.

Not every lactobacillus strain produces all the factors mentioned above. That's the reason why some strains are more effective against specific infections than others. For instance, women with $\mathrm{H}_{2} \mathrm{O}_{2}$-producing lactobacilli have a lower risk of suffering from Bacterial Vaginosis, than women whose lactobacilli don't produce $\mathrm{H}_{2} \mathrm{O}_{2}$ (Hillier et al 1992a). Unfortunately, there are also some microorganisms, whose growth is not or only marginally inhibited by lactobacilli (e.g. Streptococci and Candida). However, we can assume that lactobacilli are the main regulating factor of the vaginal milieu. Vaginal $\mathrm{pH}$ measurement gives us insight-like peering through a keyholeinto this protective bio-system (Fig. 1). Vaginal $\mathrm{pH}$ measurement is therefore of essential value. It was already used in 1892 by Döderlein in order to distinguish pathological from normal vaginal fluid (Döderlein 1892).

\section{OUR PREMATURITY—PREVENTION PROGRAM}

After having been engaged in this field for more than 3 decades in 1989 we developed a new prematurity-prevention-program which is based mainly on the ascending infection concept. The

${ }^{1}$ Screening for urinary tract infections is in many countries already part of routine care for pregnant women. 


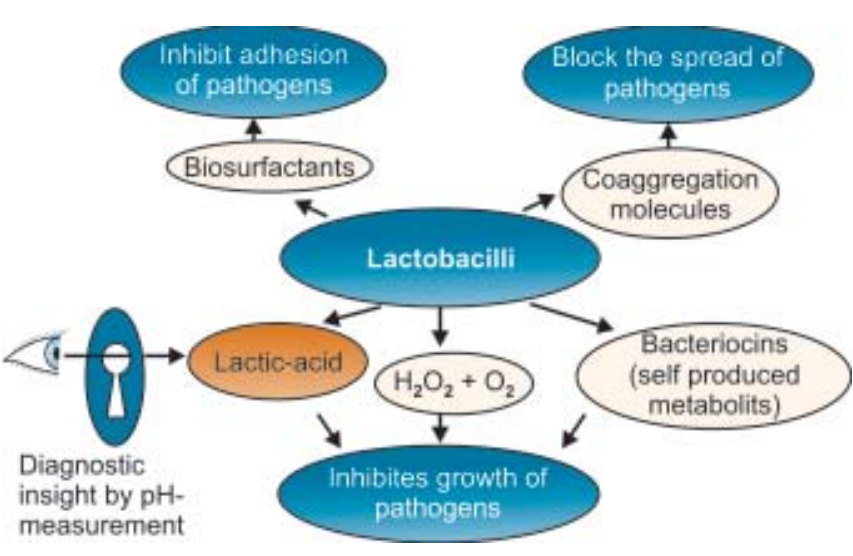

Fig. 1: Protective vaginal bio-system: Functions of Lactobacillii (modified after Reid 2001) combined with our assessment that vaginal $\mathrm{pH}$ measurement allows a diagnostic insight into this protective system like looking through a keyhole

original part with its four stages is intended for physicians. This overview, because of its comprehensive content, is less suited for a detailed presentation within such a contribution. Therefore, we will limit our discussion to the essential part of this program. More details about this program and references are found on our homepage: www.saling-institut.de.

The first stage is based on anamnestic load. A potentially increased risk is given in cases with anamnestic load such as one or more previous late spontaneous abortions or very premature labor. The best prophylactic countermeasure is to perform an operative Early Total Cervix-Occlusion at about $12 \mathrm{gw}$ to create a barrier against the ascension of organisms.

The second early stage of increased risk contains cases with a disturbance of the vaginal milieu -we consider it a "precursor"-which mostly can be detected by simple $\mathrm{pH}$ measurement at the introitus. In such a case of so-called dysbiosis, a treatment with Lactobacillus acidophilus preparations on its own is recommended.

The third stage of increased risk includes cases without symptoms of premature labor, but in which proven vaginal infection is present such as bacterial vaginosis, Chlamydia infection of the cervical canal or urethra or significant bacteriuria. In such cases, antiseptic, respectively local chemotherapeutic measures and local or systemic antibiotic therapy are recommended. The chances of success are still favorable.

The fourth and most progressed stage involves cases with symptoms of prematurity such as apparent premature uterine contractions and/or critical ultrasonic findings of the cervix. In this last stage, the therapeutic measures are increasingly unsuccessful.

Another important risk of prematurity which belongs to our medical part of the prevention program is the occurrence of significant bacteriuria which has been known as a cause of prematurity for a long time. Also, in the last decade, evidence was found for correlations between parodontitis and premature births (for example, see Offenbacher 1998).

\section{Screening for Pre-infection Respectively Infection Signs}

The main emphasis of our program lies however, in screening each pregnant woman for pre-infection signs, or if this has been started too late, for infection signs. We assume that the unexpected high successes in the reduction of prematurity rates-achieved by our self-care-measures are based on the following new opportunity: never before it was possible to detect the first disturbances of vaginal milieu at such an early stage and to start with therapeutic countermeasures so early (see also under Self-Care Program).

In cases where prematurity is caused due to other reasons, the possibility of intervention and successful therapy are clearly not so good. The measurement of the vaginal $\mathbf{p H}$-value is particularly important. We have been recommending this measure already since 1989 (Saling 1990) for the regular prenatal care. Currently we are performing an inquiry with regard to regular prenatal care in Germany at the present time. According to our first evaluation, about $2 / 3$ of the physicians, who returned the forms, do measure the vaginal $\mathrm{pH}$ of their patients regularly. An increase in the $\mathrm{pH}$-value $(>4.2$ if measured with $\mathrm{pH}$-meter, $>4.4$ if measured with indicator paper) ${ }^{2}$ can refer to:

- Disturbance in the vaginal milieu, the so-called "dysbiosis"

- Bacterial vaginosis. Diagnostic clinical criteria (after Amsel et al 1983) in addition to an increased vaginal $\mathrm{pH}(>4.5)$ are suggestive

- Aerobic vaginitis described by Donders et al (2002)

- More rarely another infection. If other infections are suspected, an appropriate examination should be carried out.

The treatment will be performed according to the situation. Here are just the most common indications:

1. Disturbances of the vaginal milieu without signs of bacterial vaginosis or other specific infection: after our experiences lactobacillus preparations provide the best treatment in these cases.

2. If bacterial vaginosis is diagnosed it should be treated either locally or systemically with Metronidazole or Clindamycin.

3. Other specific infections should be treated accordingly.

\section{SELF-CARE-PROGRAM FOR PREGNANT WOMEN}

The "Self-Care"-measures for pregnant women form the most important part of our Prematurity-Prevention-Program (Saling 1998, Saling et al 1998, 2001). We recommend that each 
pregnant patient measures her vaginal $\mathbf{p} \mathbf{H}^{2}$ from the beginning of the pregnancy using a CarePlan ${ }^{\circledR} \mathrm{VpH}$-test-glove which we developed in collaboration with a Medical Company. The indicator can be compared with a color chart and the $\mathrm{pH}$-value read. If the $\mathrm{pH}$ is normal, this means 4.4 or less the indicator turns yellow (Fig. 2).

If the $\mathrm{pH}$ is measured twice a week by the patient herself the intervals between measurements are greatly reduced to one eighth (1/8) compared with the normal prenatal care examination by the physician once every four weeks. The substantially superior chances for very early detection of risk symptomsup to now not achievable at all—and the corresponding countermeasures that can be performed so early are apparent, when the patient herself is involved in the action.

If a pH-value of $\mathbf{4 . 7}$ or more is measured, the pregnant patient is advised to consult her doctor as soon as possible to ascertain the background, and if necessary to start treatment. The test-glove packs also contain detailed information about the program for the women. In this information, she is also advised to consult her physician immediately if any of these signs are present:

- Changes in vaginal discharge

- Burning and itching in the intimate regions

- Signs of urinary tract infection

- Menstruation-like pains, etc.

- Vaginal bleeding or spotting.

For more details, please see: http://www.saling-institut.de/ eng/04infoph/03selbst.html

\section{Results}

Our results have repeatedly been published (Saling 1991, Saling et al 1991, 1998, 2001 and 2006a). Just a few results concerning the Self-Care Program should be mentioned:

- The rate of low birthweight infants $(<2500 \mathrm{~g})$ in those patients taking part in the Self-Care Program and who had been pregnant before was $6.2 \%$, this means three times less than in immediate previous pregnancies, when it had been $18.3 \%$

- It is of special interest to note that the number of very underweight infants $(<1500 \mathrm{~g})$ was $1.3 \%$, that is six times lower than in the immediate previous pregnancies, when it had been $7.8 \%$

- The rate of extremely underweight infants (< 1000 g) amounted to $0.9 \%$, as opposed to $3.9 \%$ previously.

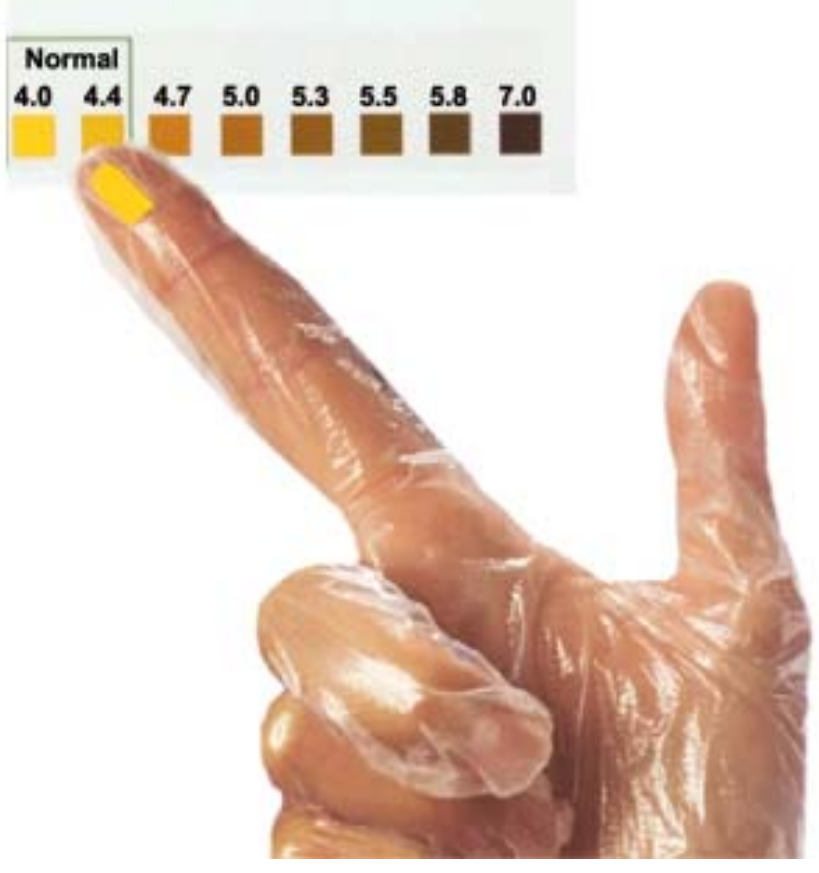

Fig. 2: $p H$-measurement: Comparison with the color scale

\section{Results from Other Places}

Later Hoyme and Cow (1998) achieved similar encouraging results with our program in a prospective project undertaken in Erfurt, the capital of Thuringia, Germany. The excellent results encouraged the Government of Thuringia to employ our program on approval in their whole state. In the second half of the year 2000, the Self-Care Program was employed and the statistically evaluated results for the entire state were compared with those from the first half of 2000 without the program (in each half-year, there have been more than 8,000 births). The results are impressive and, from our point of view, represent a breakthrough, in so far as most authors dealing with prematurity stated that in greater population areas, the prematurity rate has not changed at all during the previous decades.

In Thuringia, the results were (Hoyme et al 2002, 2004, 2005):

- With regard to gestational weeks: the rate of very early born infants with less than $32 \mathrm{gw}$ was $1.36 \%$ in the first half of the year 2000, and $0.94 \%$ in the second half. This is a significant reduction.

\footnotetext{
${ }^{2}$ Devices for the measurement of the vaginal $\mathrm{pH}$ : A simple and, if used for the examination of many patients, inexpensive way of measuring the $\mathrm{pH}$ is to use a small, portable pH-meter. Another alternative, a little more expensive, is the use of indicator strips which are introduced into the area of the introitus vaginae with the finger either before or after the vaginal examination and compared with the corresponding color scale. We made by far the best experiences, when using "Spezialindikator pH 4.0-7.0"; art-no. 1.09542 by Merck, Darmstadt (Germany), because reading is here especially easy and reliable. In the meantime, special disposable gloves with the indicator paper from Merck fixed on the index finger are available for use by the physician. The gloves are almost identical to the ones that we recommend for the patients (see below). The only difference is, that the paper in the version for the physician is attached to the middle phalanx of the index finger, so that during vaginal examination the $\mathrm{pH}$ value will be measured automatically at the lower part of the vagina.
} 
- With regard to birthweight: in infants below $1500 \mathrm{~g}$ birthweight, the rate decreased from 1.29 to $0.97 \%$. In infants with less than $1000 \mathrm{~g}$, the decrease was significant from 0.61 to $0.38 \%$. This is an even greater decrease.

- Also cases with premature rupture of membranes (PROM) have been significantly reduced. While in the first half of the year 2000, the frequency of PROM in cases where the infants have been born with less than $32 \mathrm{gw}$ was $0.55 \%$ out of 7,870 deliveries it has been significantly reduced in the 2nd half of the year to $0.2 \%$ out of 8,406 deliveries.

- In the meantime, a statistical cross check is available (Hoyme et al 2005a, 2005b): After this campaign had been finished, the prematurity rates monitored in 2002 were again as high as they had been prior to the introduction of the activities (Fig. 3 shows the numbers for children with a birthweight $<1000 \mathrm{~g}$ ). We see in these results, a confirmation for the efficiency of the program and it compensates to a certain degree the fact that randomized controlled studies are still not available (see also the discussion below).

Encouraged by these excellent results several German health insurance companies conducted our prenatal-care selfexamination program as a pilot project to their pregnant members at no charge. The companies started this project in
December 2003, the official results are not available yet, but after first internal evaluations, they have already saved a high amount of expenses.

A separate study is currently being conducted by a group of other health insurance companies in the German state NorthRhine-Westfalia with the participation of 780 gynecologists. The first results of their evaluation of the so-called "Hallo-Baby" project shows that the insured patient had a prematurity rate of $7 \%$ compared with the overall prematurity rate in NRW of $9.6 \%$ (BKK, press report 2008).

\section{PREGNANCIES WITH ANAMNESTIC RISK}

\section{Recurrent Late Abortions or Preterm Births}

After one preterm birth in the history, the risk of a recurrent preterm birth is increased (Bakketeig 1998, Iams et al 1998, Mercer et al 1999), the actual recurrence risk depending on the cause and also on the gw when the preterm birth respectively late abortion occurred: the earlier in pregnancy, the higher the risk for recurrence. McManemy et al (2007) found also, that in cases with two previous pregnancies, the risk is higher (21\%) if the sequence of previous pregnancies was term/preterm and lower (13\%) if the sequence was preterm/term. After 2 preterm deliveries the risk for recurrence is about $40 \%$ depending on

Birth weight $<1000 \mathrm{~g}$

State of Thuringia

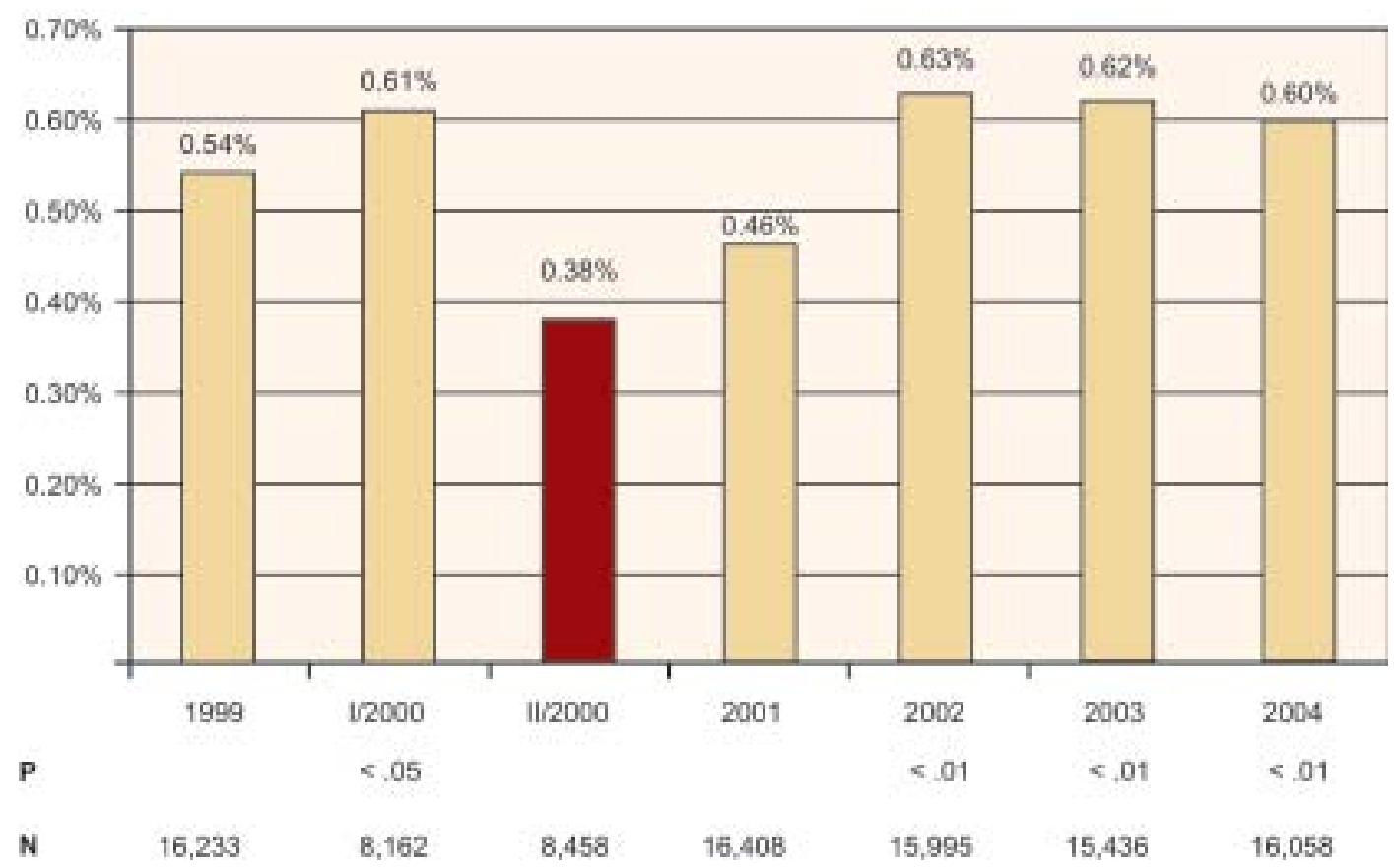

Fig. 3: Statistical crosscheck between the results from the campaign (red column) with previous and later years (after Hoyme et al 2005b) 
the gw: 33\% for 2 prior preterm deliveries between 32 to $36 \mathrm{gw}$ and 57\% in cases with 2 prior deliveries between 21 to $31 \mathrm{gw}$ (McManemy et al 2007).

Particularly in cases with two or more late abortions $(>12$ $+0 \mathrm{gw})$ or early premature births $(<32+0 \mathrm{gw})$ in the patient's history with either infection as cause for these events or when no other cause has been found, but when for instance premature rupture of membranes occurred, we recommend an Early Total Cervix Occlusion (ETCO) as preventive measure (Fig. 4, left part). Please note, that the main reason for premature rupture of the membranes is ascending vaginal infection. The Total Cervix Occlusion (TCO) creates a complete barrier against ascending infections within the cervical canal (as opposed to the cerclage, see below). We introduced this measure in 1981 (Saling 1981, 1984). The operation method is explained in detail on www.saling-institut.de, where you can also download a video about it.

The rate of surviving children after an ETCO was about $80 \%$ in our own population (as opposed to $17 \%$ in the pregnancies before the ETCO in the same group Saling 1993, Saling et al 2006b). Similarly good results have been obtained by other clinicians performing the Total Cervix Occlusion (TCO): In 1996, we reported the results of a multi-centerevaluation, in which 11 German hospitals took part (Saling and Schumacher 1996) and the outcome of a total of 819 pregnancies with TCO was assessed. It emerged that the rate of surviving infants in the pregnancies before TCO had been performed was $21 \%$ compared to $74 \%$ in the pregnancies with TCO. Hormel and Künzel (1995) reported similar good results.

This operation is now an essential part of our PrematurityPrevention-Program and also a widespread measure in German speaking countries. Our "Early Total Cervix-Occlusion" is in principle quite different from a pessary or the cerclage (see Fig. 4). The latter only allows to tighten the cervical canal. Now as before microorganisms can ascend into the uterus. Therefore, the success rate to achieve a surviving infant in pregnancies with cerclage has been only $26 \%$ compared with $80 \%$ after ETCO (Saling 1990, Saling et al. 2001). However, our operative occlusion creates a complete barrier within the cervix to prevent ascension of organisms.

Other measures concerning recurrent preterm birth, e.g. measurement of cervical length, fetal fibronectin or progesterone application are in the literature partially controversially discussed (for details see the articles from Mazaki-Tovi et al 2007, Romero 2007, Romero et al 2006a and 2006b, Varma et al 2006).

\section{Multiple Pregnancies}

Another group with higher risk are multiple pregnancies. The fact is important that our Self-Care-Program enables us to remarkably reduce the number of premature births also in multiple pregnancies. In Thuringia, the frequency of twins and

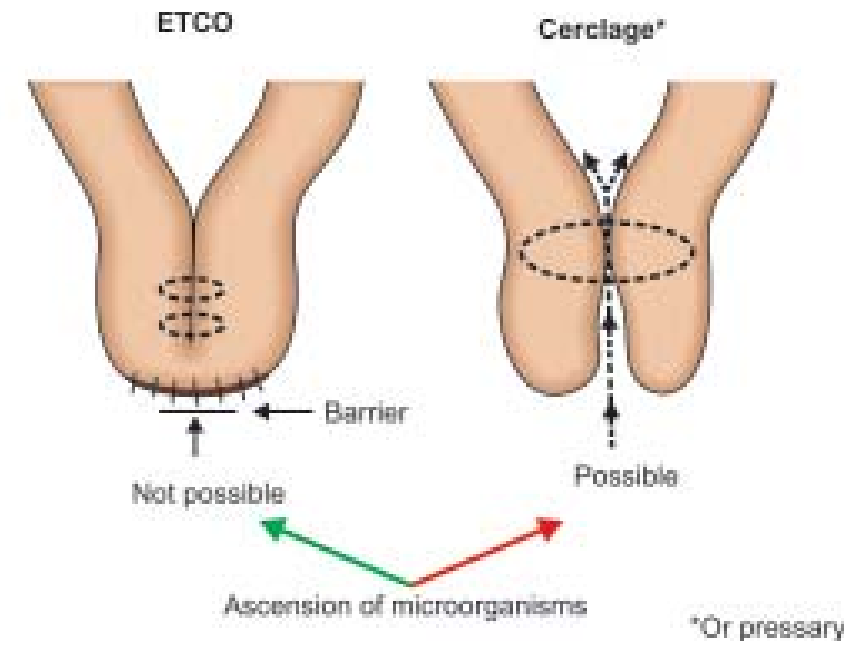

Fig. 4: Early Total Cervix Occlusion (ETCO) versus cerclage or pessary:ETCO = Early Total Cervix Occlusion ("Early" means: operation performed at $<16+0 \mathrm{gw}$ and before any anatomic changes at the cervix are detectable)

triplets with birthweight lower than 1,500 g has been reduced from about $27 \%$ without the Self-Care-Program to about $14 \%$ with the program and in the group of extreme low birthweight of less than $1000 \mathrm{~g}$ from 11.6 to 2.0\% (Hoyme et al 2005).

But there is also another new additional chance to achieve success in multiple pregnancies. The basis is an interesting measure from G Schulze. Already in 1990, Schulze started to perform our operative ETCO not only in cases with recurrent miscarriages but also in multiple pregnancies in general. With ETCO in multiple pregnancies in about 100 cases, he was able to achieve a prematurity rate of only $17 \%$ as against a rate of $29 \%$ in cases without ETCO (Schulze 2008). So in cases with ETCO, there has been a reduction of about $40 \%$. We are convinced that this is an additional efficient method to reduce the frequency of prematures in multiple pregnancies. Further research needs to be done to evaluate in which cases with multiple pregnancies screening for pre-infection signs and infections by the physician and respectively by the midwife plus additional $\mathrm{pH}$ self-measurement by the pregnant women themselves is sufficient and which patients might benefit from an additional ETCO.

\section{DISCUSSION AND CONCLUSION}

Internationally, a lot of research is done in the field of prematurity prevention. Particularly in the field of infections, there are some promising approaches, such as "graded measures", e.g. measurement of the cervical length and-if the cervix is shortening-measurement of fetal fibronectine and then according to that result further measures (For a full discussion of current research in this area, please compare Romero 2007). However, from our point of view, most of these measures start at an already advanced stage of the prematurity process. 
Also, we should not rely too much on the opinion that most things in medicine are or must be very complicated. No, apart from such complexes like for instance in our field "Great Obstetrical Syndromes” (Romero 2006b) there are also surprisingly simple solutions to prevent risks of health. As we for instance know from history of puerperal sepsis, Ignaz Semmelweis has shown that an elementary measure like washing the hands with disinfectants can prevent infection and can save many human lives. Naturally we can be proud of the current fascinating often highly sophisticated progress in human medicine, particularly in last decades in our pre- and perinatal medicine. But we should not ignore or forget that there arenow as before-also simple ways to achieve safety for our patients.

Currently, the Self-Care Program-as has been confirmed by our evaluation and afterwards by two prospective investigations by Hoyme and Co._-seems to be the most efficient, easily applicable and inexpensive program for prevention of very early prematurity. The explanation of the so positive results which we achieved, may be due to the fact that our prevention program, which appears to be elementarily simple-with the help of the cooperating pregnant patient-allows to detect the very first disturbances of the vaginal ecosystem long enough before any concrete symptoms of infectionincluding bacterial vaginosis and aerobic vaginitis-are evident. This enables immediate therapeutic measures, leading to a rapid re-establishment of normal vaginal milieu and probably prevents some of the later stages of the so complicated prematurity complex or how it was named by Professor Roberto Romero as one of the "Great Obstetrical Syndromes".

Thus, the Self-Care-Program for pregnant women has a high importance in the field of health and social care and has considerable value within our social community. We therefore recommend this measure for all pregnant women as a basic procedure. In countries where the circumstances do not allow to employ the self-care measures for all women, at least $\mathrm{pH}$ measurement by physicians or midwives should be performed regularly. Additionally other, more sophisticated measures, may be necessary in special cases. For women with recurrent preterm births with either infection as cause for these events or when no other cause has been found, from our point of view the ETCO is the best solution.

\section{Randomized Studies and Evidence Based Medicine}

We are aware, that in times of evidence-based medicine prospective randomized trials are-or at least seem to be"standard of art" to prove the effectivity of a given measure. But we should not rely too much on the current and so dominating opinion that "randomized controlled studies" and the so-called "evidence based medicine" are the only reliable ways to differentiate between efficient and inefficient medical measures. Such simple maneuvers like washing the hands has never been proved by randomized controlled studies (Semmelweis performed rather an "observational study") but nevertheless his measure was highly efficient and a real breakthrough.

We should not renounce on simple practical thinking and should at the same time use our common sense. Also old traditional methods had their validity of finding out efficient diagnostic and therapeutic processes. We are not alone with such opinions. So for instance Peter Dunn a well-known British neonatologist published the following statement: "Nor do I need to remind you that Medicine is an Art as well as a Science and that every patient-allow me to include every midwife and every physician-is a unique individual who does not necessarily conform to the conclusion of a metaanalyzer. We must be careful not to rely on high technology to the extent that we allow our clinical skills and judgement to atrophy” (Dunn, 1998).

Therefore, although it would be possibly more convincing for the international community, if we had randomized trials for both the Self-Care-Program and the ETCO, we don't think that it is necessary to prove its efficiency. Also, after the above discussed good results and also after the study performed by several health insurances companies, it seems to be impossible to perform a randomized trial in Germany. It is most unlikely that after all these results a protocol for a randomized study with some women measuring their $\mathrm{pH}$-value and some not (or without therapeutic consequences) would pass any ethical council in Germany and in any case, our own ethical conscience would not allow to design such a study. The same argument is valid for the ETCO. It is by now a widespread measure in Germany $^{3}$ with excellent results.

The situation may be different in countries where either the measurement of the vaginal $\mathrm{pH}$ by the physician and/or the self measurement by the women themselves is not yet performed that widely. The same is true for the ETCO. Therefore, if individual scientists or study groups consider a randomized trial with either the pH-measurement or the ETCO, we would welcome it very much and would support them with any advice or assistance, if necessary.

Currently, we are preparing an "International Prematurity Prevention Project (IPPP)” aiming for international cooperation with national societies of perinatal medicine, societies of obstetrics and maternal fetal medicine, institutions of medical and social affairs within the national governments as well as individual scientists and study groups. This program is intended to incorporate easily applicable measures for the prevention of prematurity into the prenatal care of participating countries. We plan to invite these societies and individuals to

\footnotetext{
${ }^{3}$ You can find a list of clinics performing the ETCO in Germany, Switzerland and Austria on http://www.saling-institut.de/german/06contact/04clischn.htm
} 
take part in this project by evaluating and implementing either the program as a whole or only "modules" such as the vaginal $\mathrm{pH}$-measurement. Information about the IPPP will soon be available on: www.prematurity-prevention.org

\section{Further Information}

On www.saling-institut.de you can find detailed information about the Prematurity-Prevention-Program, the Self-CareProgram and the ETCO. On the Website there is also a selfmade video to be downloaded on how to perform the ETCO.

\section{BIBLIOGRAPHY}

1. Amsel R, Totten PA, Spiegel CA, Chen KCS, Eschenbach D, Holmes KK. Nonspecific vaginitis. Am J Med 1983;74:14-22.

2. Bakketeig LS, Bergsjø P. The epidemiology of preterm birth. In: Kurjak A (Ed): Textbook of Perinatal Medicine. London, New York: 1998;1331-36.

3. Berkowitz GS, Papiernick E. Epidemiology of preterm birth. Epidemiol Rev 1993;15(2)414-43.

4. BKK Landesverband Nordrhein-Westfalen, Presseservice 2008: "Hallo Baby"-Betriebskrankenkassen in NRW senken Frühgeburtenr.at http://www.bkk-nrw.de/service/presse/ index.php?dbt_mode=view\&id=250 (07.02.2008).

5. Bundesgeschäftsstelle Qualitätssicherung (several years): BQSBundesauswertung http://www.bqs-outcome.de/

6. Döderlein A (1892). Das Scheidensekret und seine Bedeutung für das Puerperalfieber. Verlag von Eduard Besold, Leipzig.

7. Donders GGG, Vereecken A, Bosmans E, Dekeersmaecker A, Salembier G, Spitz B. Definition of a type of abnormal vaginal flora that is distinct from bacterial vaginosis: aerobic vaginitis. BJOG 2002;109:34-43.

8. Dunn PM. Perinatal reflections (Editorial). Prenat Neonat Med 1998;3:367-70.

9. Hack M, Taylor HG, Klein N, Eiben R, Schatschneider C, Mercuri-Minich N. School-age outcomes in children with birth weights under 750 g. N Engl J Med 1994;331:753-59.

10. Hack M, Flannery DJ, Schluchter M, Cartar L, Borawski E, Klein N. Outcomes in young adulthood for very-low-birthweight infants. N Engl J Med 2002;346(3):149-57.

11. Hillier SL, Krohn MA, Klebanoff SJ, Eschenbach DA. The relationship of hydrogen peroxide producing lactobacilli to bacterial vaginosis and genital microflora in pregnant women. Obstet Gynecol 1992a;79(3):369-73.

12. Hoyme UB, Grosch A, Roemer VM, Saling E. Erste Resultate der Erfurter Frühgeburten-Vermeidungs-Aktion. Z Geburtshilfe Neonatol 1998;202:247-50.

13. Hoyme UB, Möller U, Saling E. Ergebnisse und mögliche Konsequenzen der Thüringer Frühgeburtenvermeidungsaktion 2000. Geburtshilfe Frauenheilk 2002;62:257-63.

14. Hoyme U, Saling E. Effiziente Frühgeburtenvermeidung. Das Thüringer Modell. Gynakol Geburtshilfliche Rundsch 2004;44(1):2-9.

15. Hoyme UB, Schwalbe N, Saling E. Die Effizienz der Thüringer Frühgeburtenvermeidungsaktion 2000 wird durch die
Perinatalstatistik der Jahre 2001-2003 bestätigt. Geburtsh Frauenheilk 2005a;65:284-88.

16. Hoyme UB, Schwalbe N, Saling E. Efficient Prematurity Prevention is possible by $\mathrm{pH}$-self measurement and immediate therapy of threatening ascending infection. J Perinat Med 2005b;33 Suppl. 1-Oral presentations.

17. Hormel K, Künzel W. Der totale Muttermundverschluss. Prävention von Spätaborten und Frühgeburten, Gynäkologe 1995;28,181-86.

18. Iams JD, Goldenberg RL, Mercer BM, et al. The preterm prediction study: recurrence risk of spontaneous preterm birth. Am J Obstet Gynecol 1998;178:1035-40.

19. Institute of Medicine of the National Academies (2006). Preterm Birth: Causes, Consequences, and Prevention http:// www.iom.edu/CMS/3740/25471/35813.aspx

20. Mazaki-Tovi S, Romero R, Kusanovic JP, Erez O, Pineles BL, Gotsch F, Mittal P, Than NG, Espinoza J, Hassan S. Recurrent Preterm Birth. Semin Perinatol 2007;31:142-58.

21. McManemy, J, Cooke, E, Amon E, Leet T. Recurrence risk for preterm delivery. Am J Obstet Gynecol 2007;196:567.e1-567.e7.

22. Mercer, Brian M, Goldenberg, Robert L, et al. The Preterm Prediction Study: Effect of gestational age and cause of preterm birth on subsequent obstetric outcome. Am J Obstet Gynecol 1999;181 (5, Part 1):1216-21.

23. Monset-Couchard M, de Bethmann O, Kastler B. Mid- and longterm outcome of 89 premature infants weighing less than $1000 \mathrm{~g}$ at birth, all appropriate for gestational age. Biol Neonate 1996;70:328-38.

24. National Center for Health Statistics. National Vital Statistics Reports 2005;54(2), Hayattsville.

25. Offenbacher S, Beck JD, Lieff S, Slade G. Role of periodontitis in systemic health: sponstaneous preterm birth. Journal of Dental Education 1998;62(19):852-58.

26. Reid G. Probiotic agents to protect the urogenital tract against infection. Am J Clin Nutr 2001;73(Suppl):437S-443S.

27. Riegel K, Ohrt B, Wolke D, Österlund K. Die Entwicklung gefährdet geborener Kinder bis zum fünften Lebensjahr. Die Arvo Ylppö-Neugeborenen-Nachfolgestudie in Südbayern und Südfinnland. Enke-Verlag: Stuttgart, 1995.

28. Romero R, Espinoza J, Erez O, Hassan S. The role of cervical cerclage in obstetric practice: Can the patient who could benefit from this procedure be identified? Am J Obstet Gynecol 2006a;194:1-9.

29. Romero R, Espinoza J, Kusanovic JP, Gotsch F, Hassan S, Erez O, Chaiworapongsa T, Mazor M. The preterm parturition syndrome. BJOG 2006b;113(suppl 3):17-42.

30. Romero R. Prevention of spontaneous preterm birth: the role of sonographic cervical length in identifying patients who may benefit from progesterone treatment. Ultrasound Obstet Gynecol 2007;30:675-86.

31. Saigal S, Rosenbaum P, Hattersley B, Milner R. Decreased disability rate among 3-year-old survivors weighing 501 to 1000 grams at birth and born to residents of a geographi-cally defined region from 1981 to 1984 compared with 1977 to 1980. J Pediatr 1989;114:839-46. 
32. Saling E. Der frühe totale Muttermundverschluß zur Vermeidung habitueller Aborte und Frühgeburten. Z Geburtsh u Perinat 1981;185:259-61.

33. Saling E. Prevention of habitual abortion and prematurity by early total occlusion of the external os uteri. Eur J Obstet Gynecol Reprod Biol 1984;17:165-70.

34. Saling E. Zusätzliche aktuelle Maßnahmen zur Vermeidung von Spätaborten und Früh-geburten. In: Dudenhausen JW, Saling E: Perinatale Medizin, Bd. XIII (14. Deutscher Kongreß für Perinatale Medizin, Berlin 3.-6.10.1989). Thieme, Stuttgart-New York, 1990.

35. Saling E. Der totale operative Muttermundverschluß zur Vermeidung habitueller Spätaborte und sich wiederholender Frühgeburten-Fortentwicklung der Technik, weitere Erfahrungen und Ergebnisse. In: Dudenhausen JW, Saling E (Hrsg): Perinatale Medizin, Bd. XIII. (14. Deutscher Kongreß für Perinatale Medizin, Berlin, 1989). Thieme: Stuttgart, New York, S 1990;65-67.

36. Saling E, Brandt-Niebelschütz S, Schmitz C. Vermeidung von Spätaborten und risikoreichen Frühgeburten - für die Routine geeignete Maßnahmen. Z Geburtsh u Perinat 1991;195:209-21.

37. Saling E. Program for the Prevention of Prematurity. In: Hirsch HA: Infection and Preterm Labor (International Symposium Tübingen, 1990) Thieme, Stuttgart-New York 1991.

38. Saling E. Infektiologische Spätabortursachen und operativer Muttermundverschluss. Arch Gynecol Obstet 1993;254: 1265-71.

39. Saling E, Schumacher E. Der operative Totale MuttermundVerschluß (TMV). Erhebung von Daten einiger Kliniken, die den TMV einsetzen. Z Geburtshilfe Neonatol 1996;200:82-87.

40. Saling E, Al-Taie T, Lüthje J, Masur W, Placht A. Efficient and simple program including community-based activities for prevention of very small prematures. In: Kurjak A (Ed): Textbook of Perinatal Medicine. London, New York 1998;1337-44.
41. Saling E. Basic aspects of prematurity prevention and results achieved by a suitable, simple program. J Perinat Med 1998;26:466-68.

42. Saling E, Schreiber M, Al-Taie T. A simple, efficient and inexpensive program for preventing prematurity. J Perinat Med 2001;29:199-11.

43. Saling E, Schreiber M, Lüthje J. Role of operative early total cervix occlusion for prevention of late abortion and early prematurity. In: Carrera JM, Cabero L, Baraibar R: The perinatal medicine of the new millennium. Proceedings of the 5th world congress of Perinatal Medicine, Barcelona, Spain, September 2001;23-27. Monduzzi, Bologna 2001;602-07.

44. Saling E, Lüthje J, Schreiber M. Efficient and simple program including community-based activities for prevention of very early premature birth. In Kurjak A, Chervenak FA (Eds): Textbook of Perinatal Medicine. Second edition. Informa Healthcare 2006a;1401-11.

45. Saling E, Schreiber M, Lüthje J. Operative early total cervix occlusion for prevention of late abortion and early prematurity. In Kurjak A, Chervenak FA (Eds): Textbook of Perinatal Medicine (2nd edn). Informa Healthcare: 2006b;1412-16.

46. Saling E, Lüthje J, Schreiber M (2005): Late abortions and premature births-general information. http://www.salinginstitut.de/eng/04infoph/01allg.html

47. Schulze G. [Results of Early Total Cervix Occlusion (ETCO) According to Saling in Multiple Pregnancies-a retrospective study of the period 1995-2005.] Ergebnisse des Frühen Totalen Muttermundverschlusses nach Saling (FTMV) bei Mehrlingsschawangerschaften-eine retrospektive Studie der Jahre 1995-2005 Z Gebutrtsh Neonatol 2008;212:13-17.

48. Varma R, Gupta JK, James DK, Kilby MD. Do screeningpreventative interventions in asymptomatic pregnancies reduce the risk of preterm delivery-A critical appraisal of the literature. European Journal of Obstetrics and Gynecologgy and Reproductive Biology 2006;127:145-59. 